\title{
DIFERENSIASI DAN TINGKAT PEMAHAMAN PRODUK, SERTA KUALITAS SUMBER DAYA MANUSIA ATAS KEPUTUSAN NASABAH PERBANKAN SYARIAH
}

\section{DIFFERENCES AND LEVEL OF UNDERSTANDING OF THE PRODUCTS, AND THE QUALITY OF HUMAN RESOURCES FOR THE DECISION OF SHARIA BANKING CUSTOMERS}

\author{
Uswatun Khasanah'a; Afif Muamar ${ }^{2}$ \\ ${ }^{1}$ Fakultas Syariah dan Ekonomi Islam IAIN Syekh Nurjati Cirebon \\ ${ }^{2}$ Fakultas Syariah dan Ekonomi Islam IAIN Syekh Nurjati Cirebon \\ aKorespondensi: Uswatun Khasanah, email: uswatun.attasshof@yahoo.com
}

\begin{abstract}
The greater growth of the banking industry creates increasingly fierce competition between the sharia banking industry, so that it will make consumers have many alternative choices before deciding which bank to aim for sharia banking transactions. This study aims to reveal the level of understanding of the quality of human resources of customers to customer decisions, the perception of product differentiation of customer decisions. This study uses qualitative research, data collected by interview, observation, documentation and then analyzed using descriptive analysis method. The results of the study prove the customer's perception of product differentiation, the level of product understanding, and the quality of human resources have a positive influence on customer decisions in Islamic Banking. This means that according to consumers the three components are considered important when using services in Islamic Banking.
\end{abstract}

Keywords: Products, Quality of Human Resources, Customer Decisions

\begin{abstract}
ABSTRAK
Pertumbuhan industri perbankan yang semakin besar menciptakan semakin ketatnya persaingan antara industri perbankan syariah tersebut, sehingga akan membuat konsumen memiliki banyak pilihan alternatif sebelum memutuskan bank yang akan dituju untuk melakukan transaksi perbankan syariah. Penelitian ini bertujuan untuk mengungkap tingkat pemahaman kualitas sumber daya manusia nasabah terhadap keputusan nasabah, persepsi diferensiasi produk terhadap keputusan nasabah. Penelitian ini menggunakan penelitian kualitatif, data yang dikumpulkan dengan cara interview (wawancara), observasi, dokumentasi kemudian dianalisis dengan metode deskriptif analisis. Adapun hasil penelitian membuktikan persepsi nasabah dalam diferensiasi produk, tingkat pemahaman produk, dan kualitas sumber daya manusia memiliki pengaruh positif terhadap keputusan nasabah pada Perbankan Syariah. Artinya menurut konsumen ketiga komponen tersebut dianggap penting ketika akan menggunakan jasa pada Perbankan Syariah.

Kata Kunci: Produk, Kualitas Sumber Daya Manusia, Keputusan Nasabah
\end{abstract}

Uswatun Khasanah. 2020. Diferensiasi dan Tingkat Pemahaman Produk, serta Kualitas Sumber Daya Manusia Atas Keputusan Nasabah Perbankan Syariah. Jurnal Nisbah 6 (1): 15-22. 


\section{PENDAHULUAN}

Pertumbuhan ekonomi Indonesia sangat dipengaruhi oleh konsumsi domestik masyarakat Indonesia yang besar, salah satu industri yang berperan terhadap laju positifnya perekonomian Indonesia, khususnya perbankan syariah. Lembaga keuangan syari'ah di indonesia pada saat ini telah mengalami perkembangan yang sangat pesat, dimana masyarakat menilai bahwa perbankan syari'ah merupakan sarana yang aman dalam bertransaksi keuangan. Bank Syariah merupakan suatu lembaga keuangan yang berlandaskan sistem Ekonomi Islam.

Positifnya laju Perbankan syariah dewasa ini menjadi jenis komoditi perbankan yang mengalami tingkat pertumbuhan cukup tinggi. Parameter kemajuan industri perbankan syariah dapat tercermin dari seberapa besar aset yang dimiliki oleh bank umum syariah maupun unit usaha syariah yang terdapat di indonesia. Adanya Undang-Undang No. 21 Tahun 2008 tentang Perbankan Syariah yang terbit tanggal 16 Juli 2008, maka pengembangan industri perbankan syariah nasional semakin memiliki landasan hukum yang memadai dan akan mendorong pertumbuhannya secara lebih cepat. Dengan perkembangan yang mengesankan, dimana pencapaian ratarata pertumbuhan aset dalam lima tahun terakhir yaitu sekitar lebih dari 65\% per tahun, maka diharapkan industri perbankan syariah dapat berperan secara signifikan dalam meningkatkan perekonomian nasional.

Pertumbuhan industri perbankan yang semakin besar menciptakan semakin ketatnya persaingan antara industri perbankan syariah tersebut, sehingga akan membuat konsumen memiliki banyak pilihan alternatif sebelum memutuskan bank yang akan dituju untuk melakukan transaksi perbankan syariah. Dalam memilih alternatif, nasabah mempunyai persepsi yang berbeda-beda berdasarkan kemampuan sumber daya manusia. Persepsi merupakan proses yang dipakai oleh individu untuk memilih, mengorganisir, mendefinisikan informasi sehingga tercipta gambaran dunia yang mempunyai arti.

Berdasarkan latar belakang dan uraian dalam masalah penelitian ini, maka rumusan masalah nya adalah sebagai berikut, pertama, Bagaimana Tingkat Pemahaman Kualitas SDM Nasabah Terhadap Keputusan Nasabah?. Dan kedua, Bagaimana Persepsi Diferensiasi Produk Terhadap Keputusan Nasabah?.

\section{Jasa}

\section{MATERI DAN METODE}

Jasa ialah suatu pemberian kinerja atau tindakan tak kasat mata dan satu pihak kepada suatu pihak lain. Umumnya produksi dan konsumsi jasa dilakukan secara bersamaan, dilihat dari adanya interaksi antara pemberi jasa dengan penerima jasa yang mempengaruhi hasil jasa tersebut. Selain itu, jasa juga dapat diartikan sebagai suatu kegiatan yang dapat diidentifikasi dan mempunyai sifat yang tidak berwujud dan ditujukan untuk memenuhi kepuasan konsumen.

Menurut Andrian Payne (2001:9) terdapat karakteristik khusus mengenai jasa, yaitu:

1. Tidak berwujud

Pertama jasa memiliki sifat yang abstrak dimana jasa tidak bisa dilihat, dicicipi, dan disentuh seperti barang.

2. Heterogenitas

Jasa memiliki sifat yang heterogen artinya tidak ada hasil jasa yang sama walaupun dikerjakan oleh satu orang, hal ini dikarenakan jasa berupa suatu unjuk kerja.

3. Tidak dapat dipisahkan

Jasa umumnya dihasilkan dan dikonsumsi dalam waktu yang bersamaan, dengan adanya keterlibatan konsumen dalam proses tersebut. Maka dari itu, konsumen 
diharuskan ada pada tempat jasa diminta, sehingga konsumen melihat dan bahkan berpartisipasi dalam proses produksi jasa tersebut.

4. Tidak tahan lama

Jasa bukan merupakan hal yang berwujud dan terlihat sehingga jasa tidak dapat disimpan, dijual ulang kepada konsumen lain, atau bahkan dikembalikan kepada penjual/ produsen. Jasa hanya dapat langsung dirasakan oleh konsumen pada saat yang bersamaan ketika jasa tersebut diproduksi. Jadi, jasa tidak bisa dijadikan persediaan dan tidak tahan lama.

\section{Pemasaran Bank}

Menurut Kotler dan Amstrong (1992), strategi pemasaran merupakan pendekatan utama yang akan dimanfaatkan oleh unit bisnis dalam menjangkau sasaran yang telah ditentukan terlebih dahulu,. Ruang lingkup pemasaran diantaranya ketetapan pokok tentang target pasar, pemetaan produk di pasar, marketing mix dan tingkat biaya pemasaran yang dibutuhkan. Terdapat beberapa konsep dalam pemasaran diantaranya:

1. Konsep Produksi

Konsep produksi adalah konsep yang memfokuskan kepada volume produksi yang sebesar-besarnya dengan harga serendah mungkin.

2. Konsep Produk

Konsep produk merupakan konsep yang mengutamakan kualitas produk itu sendiri, tampilan produk dan karakteristik yang terbaik.

3. Konsep Penjualan

Konsep penjualan lebih menitikberatkan pada usaha-usaha promosi yang besar-besaran dan gencar dilakukan oleh karenanya pemasaran harus lebih agresif.

4. Konsep Pemasaran

Penekanan pada konsep ini adalah pada penetapan kebutuhan, keinginan, dan minat pasar. Selain itu juga dapat memuaskan pelanggan sehingga menciptakan kesejahteraan bagi konsumen dan masyarakat.

\section{Bank Syariah}

Bank syariah menjadikan Al-Qur'an dan Hadits sebagai landasan utama dalam kegiatan operasionalnya dan menganut prinsip muamalah. UU Republik Indonesia Nomor 21 Tahun 2008 telah menyatakan bahwa kegiatan usaha perbankan syariah merujuk pada fatwa yang ditetapkan oleh lembaga berwenang, yaitu DSN (Dewan Syariah Nasional) yang bernaung dibawah MUI (Majelis Ulama Indonesia).

\section{Keputusan Nasabah}

Menurut Kotler (1999), keputusan pembelian adalah tahap penilaian keputusan menyebabkan konsumen membentuk pilihannya di antara beberapa merk yang tergabung dalam perangkat pilihan. Pengharapan konsumen dibangun berdasarkan pengalaman konsumen itu sendiri, saran teman-teman dan iklan yang diluncurkan perusahaan jasa. Konsumen memilih membeli jasa berdasarkan pengharapan ini. Proses sebelum sampai kepada keputusan membeli konsumen menjalani tahapan proses pengambilan keputusan (Desiana, 2018).

\section{Diferensiasi Produk}

Diferensiasi produk adalah keunggulan pokok yang dimiliki oleh industri perbankan syariah, dimana produk-produk yang ditawarkan oleh industri perbankan syariah sangat beragam dibandingkan dengan industri perbankan pada umumnya. Diferensiasi produk adalah kegiatan memvariasikan produk agar lebih menarik. Terdapat tiga tahapan dalam proses diferensiasi, pertama adalah menemukan model nilai konsumen, bank harus menciptakan semua daftar produk dan jasa yang berdampak pada persepsi konsumen yang menjadi sasaran pasar terhadap nilai. Kedua dengan membangun tingkatan nilai konsumen, bank harus mengatur setiap faktor kedalam satu kelompok dari empat kelompok, yaitu: 
dasar (basic), harapan (expected), keinginan (desired), kejutan (unanticipated). Ketiga adalah menemukan sepaket nilai konsumen, bank harus memilih kombinasi antara faktor yang nyata dan tidak nyata untuk membedakan dengan pesaing serta menciptakan konsumen yang memiliki loyalitas.

\section{Sumber Daya Manusia (SDM)}

Sumber daya manusia (SDM) merupakan aset utama dan besar pengaruhnya terhadap kemajuan suatu perusahaan. Untuk mencapai apa yang telah menjadi tujuan perusahaan yang telah ditetapkan, maka perusahaan harus mampu membentuk manusia yang bermotivasi kuat dan berani melihat perubahan sebagai suatu tantangan yang harus dihadapi. Salah satu pendekatan dalam peningkatan sumber daya manusia adalah melalui agama.

\section{Metode Penelitian}

Penelitian ini akan dilaksanakan selama 1 bulan. Peneliti mengambil lokasi penelitian di Bank Syariah Mandiri KC Cirebon Siliwangi. Penelitian ini merupakan penelitian kualitatif dimana hasil penelitian kualitatif menitikberatkan pada makna. Penggunaan populasi dalam penelitian ini adalah nasabah seluruh Bank Syariah Mandiri dengan sampel lima orang sebagai informan wawancara. Penelitian ini menggunakan teknik random sampling, peneliti melakukan pengambilan sampel dengan memberikan hak yang sama kepada setiap subyek untuk memperoleh kesempatan dipilih menjadi sampel dan diambil secara acak.

Adapun data yang digunakan dalam penelitian ini adalah data sekunder dan primer. Data primer diperoleh penulis melalui wawancara kepada narasumber, sedangkan untuk data sekunder penulis memperoleh dari kajian literatur yang seusia dengan penelitian, jurnal, file dan dokumentasi yang tersedia, berita surat kabar serta dokumen pendukung lainnya.

Teknik pengumpulan data yang digunakan penulis dalam penelitian ini ada beberapa teknik diantaranya, observasi yaitu dengan melakukan pengamatan langsung mengenai sistem operasional dan kegiatan-kegiatan yang dilakukan di Bank Syari'ah Mandiri Kantor Cabang Cirebon Siliwangi. Penulis juga melakukan wawancara secara langsung dengan nasabah di Bank Syariah Mandiri Kantor Cabang Cirebon Siliwangi. Selain itu, penulis mendapatkan informasi tambahan dari dokumentasi yang berasal dari arsip Bank Syariah Mandiri Kantor Cabang Cirebon Siliwangi, dokumendokumen, formulir-formulir dan sebagainya untuk mendukung informasiinformasi yang diperlukan untuk penelitian. Selain meminta dokumen dari bank, penulis juga mengambil beberapa referensi yang berasal dari internet dan lain sebagainya.

\section{HASIL DAN PEMBAHASAN}

\section{Gambaran Umum Lokasi Penelitian}

Bank Syariah Mandiri Kantor Cabang Cirebon Siliwangi merupakan perusahaan yang bergerak dalam bidang ekonomi berbasis Islam yang terdapat hukum-hukum Islam yang kokoh di dalamnya. Bank Syariah Mandiri Kantor Cabang Cirebon Siliwangi beralamat di Jl. Siliwangi No.102, Kejaksan, Kec. Kejaksan, Kota Cirebon, Provinsi Jawa Barat.

Jumlah pegawai di Bank Syariah Mandiri Kantor Cabang Cirebon Siliwangi pada saat itu kurang lebih 13 orang, pada saat itu produk unggulan adalah Tabungan Mabrur, Tabungan Mudharabah, Tabungan Mabrur, dan Pembiayaan KPR. Adapun jadwal jam kerja yang dilaksanakan di Bank Syariah Mandiri Kantor Cabang Cirebon Siliwangi dari hari Senin-Jum'at atau selama 5 hari dari pukul 08.00-15.00 Wib. Di teras depan Kantor juga terdapat ATM yang dapat mempermudah nasabah untuk bertransaksi dapat digunakan oleh nasabah kapanpun karena 24 Jam 7 hari. 
Bank Syariah Mandiri sebagai bank yang beroperasi atas dasar prinsip syariah Islam menetapkan budaya perusahaan yang mengacu kepada sikap akhlaqul karimah (budi pekerti mulia), yang terangkum dalam lima pilar yang disingkat SIFAT, yaitu: Siddiq (integrasi), Istiqomah (konsistensi), Fathanah (profesionalisme), Amanah (tanggung jawab), Tabligh (kepemimpinan).

\section{Persepsi Nasabah Terhadap Keputusan Nasabah Bank Syariah Mandiri}

Persepsi bersifat individual artinya dapat dikemukakan berdasarkan perasaan, kemampuan berpikir, pengalaman-pengalaman individu tidak sama, maka hasil persepsi akan berbeda antara individu satu dengan individu lainnya. Persepsi konsumen akan diketahui dengan mengukur nilai kegunaan relatif penting suatu atribut yang terdapat suatu produk atau jasa sehingga dapat menimbulkan daya tarik pertama yang dapat mempengaruhi konsumen.

Dari data yang diperoleh penulis melalui wawancara kepada nasabah BSM dengan menjawab pertanyaanpertanyaan responden sebagai anggota sampel. Ada beberapa hal yang perlu dianalisis berdasarkan rumusan masalah yakni bagaimanakah persepsi nasabah dalam memilih produk Bank Syariah Mandiri? Artinya responden diminta menjawab dan memilih produk apa yang mereka gunakan dan memberikan alasan mengapa mereka memilih produk tersebut.

\section{Analisis Hasil Temuan Penelitian}

Responden peneliti ini adalah nasabah Bank Syariah Mandiri KCP Cirebon Siliwangi. Dari beberapa produk di Bank Syariah Mandiri KCP Cirebon Siliwangi, ternyata produk simpanan yang banyak diminati oleh nasabah Bank Syariah Mandiri KCP Cirebon Siliwangi yaitu tabungan BSM dengan akad mudharabah muthlaqah dan akad wadiah, sedangkan produk-produk yang lainnya kurang mendapatkan perhatian dari nasabah, hanya sebagian kecil nasabah yang memilih produk itu. Menurut analisis peneliti, hal ini disebabkan oleh kurangnya pengetahuan dan pemahaman nasabah terhadap produk-produk Bank Syariah Mandiri. Nasabah yang tidak mengetahui secara pasti jenis-jenis yang ada di BSM ini menganggap demikian karena memang keterbatasan mereka akan pengetahuan serta minimnya edukasi yang mereka dapatkan dari praktisi perbankan maupun di mediamedia lainnya.

Pada prinsipnya penelitian ini bertujuan untuk mencari jawaban terhadap rumusan masalah yang telah dikemukakan pada bagian sebelumnya, dimana tujuannya adalah untuk mengetahui pengaruh diferensiasi produk, tingkat pemahaman produk, dan kualitas sumber daya manusia terhadap keputusan nasabah, baik secara wawancara dan pengamatan.

Adapun hasil wawancara responden dapat dideskripsikan sebagai berikut:

1. Pemahaman Kualitas SDM Nasabah Terhadap Bank Syariah

Bank Syariah adalah lembaga keuangan syariah yang kegiatan operasionalnya menghimpun dan menyalurkan uang berdasarkan syariat islam. Dalam bank syariah akad yang dilakukan memiliki konsekuensi dunia dan akhirat karena akad yang dilakukan berdasarkan hukum islam. Setiap akad dalam perbankan syariah baik dalam hal barang, pelaku, transaksi maupun ketentuan lainnya haruslah memenuhi syarat. Hal ini diperkuat oleh responden Sri Mulyanah : "Bank syariah melakukan transaksi nya berdasarkan akad syariah berdasarkan hukum syariah

Perekonomian di Indonesia saat ini melakukan persaingan semakin kuat di era milenial. Apalagi ditambah gerakan-gerakan perekonomian islam 
mendunia. Hal ini diperkuat oleh responden Oji : "Perbankan Syariah saat ini sedang gencar-gencarnya melakukan persaingan di perekonomian di Indonesia."

Persebaran bank syariah memiliki dampak positif untuk bergerak ke perekonomian yang berbasis syariah. Hal ini diperkuat oleh responden Anah : "Perbankan Syariah saat ini market share nya sekitar 5\%, tetapi banyak lembaga keuangan lainnya yang mengikuti kesyariahan. Apalagi pemerintah mencanangkan ekonomi syariah di Indonesia dan berpedoman pada prinsip syariah".

Perkembangan lembaga keuangan bank syariah semakin bernilai baik untuk memenuhi kebutuhan masyarakat. Hal ini diperkuat oleh responden Risky : "Luar biasa menjadi bank syariah terbesar di Indonesia" dan diperkuat oleh responden Daim : "Bank Syariah saat ini tuh memang sangat baik karena memang perkembangannya pesat dan banyak sekali UMKM dan masyarakat terbantu oleh bank syariah. Namun untuk saat ini masyarakat yang awam belum pada tau adanya bank syariah dan produkproduknya"

Perkembangan perbankan syariah di Indonesia memiliki tampilan yang baik untuk masyarakat misalnya Bank Syariah Mandiri salah satu bank syariah terbesar di Indonesia yang saat ini memiliki kemajuan dari segi aset tertinggi dan fasilitas pelayanannya baik. Hal ini diperkuat oleh responden Oji : "Di BSM memiliki layanan yang baik dan fasilitasnya baik" dan diperkuat oleh responden Sri Mulyanah : "BSM memiliki layanan bagus, dekat dengan rumah, atm nya juga lumayan banyak". diperkuat oleh responden Anah : "Bank Syariah Mandiri merupakan Bank Syariah pertama yang memiliki aset terbesar di Indonesia, selain itu juga layanan dan fasilitasnya memadai"

2. Diferensiasi Produk Terhadap Keputusan Nasabah

Produk bank syariah memiliki daya saing dan inovatif dalam memberikan pelayanan yang baik. Hal ini diperkuat oleh responden $\mathrm{Oji}$ : "produk nya menarik dan inovatif sehingga nasabah lebih cepat memutuskan dengan baik". Suatu produk juga harus difasilitasi fiturfitur untuk mendukung dalam akses transaksi nasabah. Hal ini diperkuat oleh responden Sri Mulyanah : "Produk-produk di Bank Syariah Mandiri sangat baik, misalnya dalam gaya feature produk nya menarik sehingga saya tertarik untuk jadi nasabah". Dan diperkuat oleh responden Anah : "Produk-produknya nyaman dan dilengkapi dengan layanan e-banking BSM untuk memudahkan transaksi, produk BSM memiliki modifikasi yang baik dan unggul pada dimensi keistimewaan, maupun rancangan dari produk itu sendiri".

$$
\begin{array}{lll} 
& \text { Masyarakat dalam bertransaksi } \\
\text { di Bank Syariah berdasarkan }
\end{array}
$$
kebutuhan nasabah misalnya di BSM memiliki produk keunggulannya yaitu produk simpanan seperti tabungan ku dengan akad mudharabah dan akad wadiah. Hal ini diperkuat oleh responden Oji : "tabungan dengan akad mudharabah, karena ada bagi hasil nya". Dan diperkuat oleh responden Anah : "Produk Tabungan Wadiah, karena ga ada bunga dan ga ada biaya admin nya". Transaksi yang dilakukan nasabah pada BSM adalah menabung, tarik tunai dan transfer. Hal ini di perkuat oleh responden Oji : "transaksi yang biasa dilakukan itu menabung, transfer". Dan diperkuat oleh responden Risky : "Transfer antar bank, tarik tunai, menabung". 
Berdasarkan hasil wawancara dengan responden, persepsi nasabah dalam diferensiasi produk, tingkat pemahaman produk, dan kualitas sumber daya manusia memiliki pengaruh positif dan signifikan terhadap keputusan nasabah pada Perbankan Syariah. Artinya menurut konsumen ketiga variabel tersebut dianggap penting ketika akan menggunakan jasa pada Perbankan Syariah.

\section{KESIMPULAN DAN IMPLIKASI}

Berdasarkan penelitian yang telah dilakukan diatas, maka dapat diambil kesimpulan sebagai berikut, pertama, Keputusan nasabah dalam menggunakan jasa perbankan syariah dipengaruhi oleh diferensiasi produk yang berdasarkan persepsi nasabah. Keputusan nasabah dalam memilih produk yang ada di BSM dipengaruhi oleh pengetahuan informasi, hal ini dikarenakan memudahkan nasabah untuk cepat mengetahui produkproduk BSM. Kedua, dari jenis-jenis produk simpanan yang ada di BSM hanya tabungan BSM yang paling banyak diminati nasabah Bank Syariah Mandiri KCP Cirebon Siliwangi serta alasan mereka memilih produk tersebut karena produk BSM sesuai syariah, halal dan aman. Transaksi yang dilakukan oleh nasabah adalah menabung, transfer antar bank dan tarik tunai.

\section{DAFTAR PUSTAKA}

Adi Nugroho, Riyogo. "Pengaruh Strategi Diferensiasi Produk, Merek, Dan Promosi Terhadap Keputusan Pembelian Sepeda Motor Satria F150: Hyper Underbone", Jurnal Manajemen \& Bisnis 9:1 (2013): 1-9

Bank Indonesia, "Sekilas Perbankan Syariah di Indonesia." L Lihat. Https://www.bi.go.id/id/perbankan
/syariah/Contents/Default.aspx. Diakses tanggal 26 september 2019 .

Bhirawa Anoraga. "Motivasi Kerja Islam

Dan Etos Kerja Islam Karyawan

Bank Jatim Syariah Cabang

Surabaya", Jurnal ini merupakan

bagian dari skripsi 2:7 (Juli:2015)

Desiana, et al. "Faktor-Faktor Yang Mempengaruhi Keputusan Nasabah Untuk Menggunakan Jasa Perbankan Syariah Di Kota Tasikmalaya", Akuntabilitas: Jurnal Ilmu Akuntansi 11:1 (2018): 23-34

Ikatan Bankir Indonesia, Memahami Bisnis Bank Syariah, (Jakarta : PT Gramedia Pustaka Utama, 2016), HIm. 7

Malik, Muhammad Ehsan, et al. "Impact of Brand image and Advertisement on Consumer Buying Behavior", World Applied Sciences Journal 23:1 (2013): 1-6

Raje, Archana dan Khanna, Vandana Tandon. "Impact of E Service Quality On Consumer Purchase Behaviour In An On Line Shopping", IJCSMS International Journal of Computer Science and Management Studies 12, (April 2012): 1-5

Simamora, Idham Kurnia, dkk. "Pengaruh Harga, Citra Merek, Positioning, Dan Diferensiasi Produk Terhadap Keputusan Pembelian Konsumen Pada Produk Jamu PT. Njonja Meneer", Diponegoro Journal of Social And Politic (2013): 1-12

Soeratno dan Arsyad, Lincolin. Metode Penelitian untuk Ekonomi dan Bisnis Yogyakarta: UPP AMP YKPN,1988.

Tanzeh, Ahmad. Pengantar Metode Penelitian. Yogyakarta: Teras, 2009. 
Widagdo. Herry. "Analisis Pengaruh Kualitas Layanan Dan Promosi Terhadap Keputusan Konsumen Membeli Komputer Pada PT. XYZ Palembang", Forum Bisnis Dan Kewirausahaan Jurnal Ilmiah STIE MDP 1:1 (2013): 1-10 